\title{
Contracts Discharged Through Breach: RESTITUTION FOR SERVICES RENDERED BY THE INNOCENT PARTY
}

\author{
NiChOlaS RAFFERTY
}

The author examines the autonomous claim in unjust enrichment available to a party who has elected to treat a contract as discharged because of the defendant's fundamental breach. In this context. he concentrates upon the claim in respect of services rendered and addresses the primary questions that arise in the law of restitution: What factor renders the defendant's enrichment unjust? Has the defendant in fact been enriched? How should the defendant's enrichment be valued? The author suggests answers to these basic questions, but he also tries to show that there is little need to give a plaintiff, faced with a repudiatory breach, an alternative claim in restitution. The plaintiff should be restricted to a claim for damages for breach of contract. The plaintiff has chosen to make the contract on the terms agreed and there is nothing unfair in limiting the remedies to that bargain.
$L$ 'auteur examine les motifs susceptibles de fonder une poursuite pour enrichissement sans cause que peut invoquer une partie estimant qu'il y a eu cessation de contrat parce que le défendeur a manqué à une obligation. Il se penche surtout sur les services rendus et répond aux principales questions du droit en matière de restitution : Quels sont les facteurs rendant l'enrichissement injustifié? $Y$ a-t-il eu enrichissement? Comment en évaluer le montant? $L$ 'auteur tente de répondre à ces questions mais démontre également qu'il n'est pas vraiment nécessaire de donner au demandeur la possibilité de poursuivre en restitution et qu'il devrait s'en tenir $\dot{a}$ une réclamation en dommages-inté rèts pour rupture de contrat. Le demandeur a choisi de conclure le contrat aux termes de conditions mutuellement convenues et il n'est pas injuste d'en limiter les redressements.

\section{TABLE OF CONTENTS}

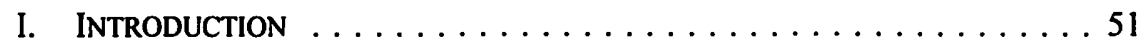

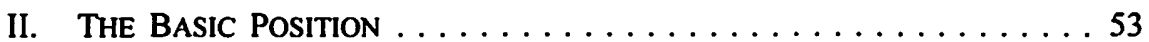

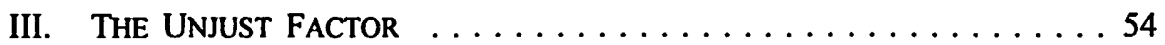

IV. THE ENRICHMENT $\ldots \ldots \ldots \ldots \ldots \ldots \ldots \ldots \ldots \ldots \ldots \ldots$

V. VALUATION OF THE ENRICHMENT -

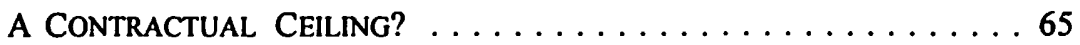

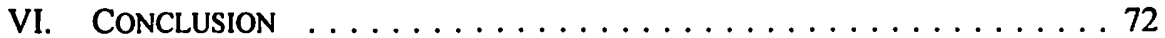

\section{INTRODUCTION}

The central theme underlying the law of restitution is unjust enrichment. Section 1 of the groundbreaking Restatement of the Law of Restitution, ${ }^{\prime}$ published in 1937, states boldly: "A person who has been unjustly enriched at the expense of another is required to make restitution to the other." Echoing this sentiment, Lord Goff, co-author of the leading English textbook on restitution, ${ }^{2}$ wrote while sitting as a trial judge:

Professor of Law, The University of Calgary.

(St. Paul: American Law Institute Publishers, 1937).

Lord Goff \& G. Jones, The Law of Restitution, 4th ed. (London: Sweet and Maxwell, 1993). 
[A] claim [for restitution], being founded on the principle of unjust enrichment, presupposes three things: (1) receipt by the defendant of a benefit, (2) at the plaintiff's expense, (3) in such circumstances that it would be unjust to allow the defendant to retain the benefit. ${ }^{3}$

In Canada, the traditional formulation has been slightly different, though to similar effect. Thus, in Rathwell v. Rathwell, ${ }^{4}$ for example, Dickson J. said:

As a matter of principle, the Court will not allow any man unjustly to appropriate to himself the value earned by the labours of another.... [F]or the principle to succeed, the facts must display an enrichment, a corresponding deprivation, and the absence of any juristic reason - such as a contract or disposition of law - for the enrichment.

Birks ${ }^{6}$ has shown that the law of restitution can be divided into two broad parts. First, there is the autonomous claim in unjust enrichment, where the benefit to the defendant is acquired "by subtraction from" the plaintiff. Second, there is the dependent restitutionary claim for wrongs, where the defendant has gained a benefit, bearing no necessary relation to any loss suffered by the plaintiff, "by doing wrong to" the plaintiff. The independent claim in unjust enrichment fits most clearly within the standard formulation of the principle of unjust enrichment, and especially the Canadian variation thereof. As Smith has pointed out, the Canadian version speaks of the need for "a corresponding deprivation" to the plaintiff whereas the Restatement and Lord Goff talk more ambiguously of the defendant having acquired a benefit "at the plaintiff's expense."7

This article focuses upon autonomous unjust enrichment in the context of contracts discharged for breach. Thus, it does not address the interesting and complex question of whether, and to what extent, a plaintiff is entitled to recover the profits realized by a defendant from breaking a contract with the plaintiff. ${ }^{8}$ More particularly, this article concentrates upon the position of the innocent party in the context of the rendering of services. It addresses the two fundamental questions that arise in any claim in unjust enrichment: Was the defendant enriched, and would it be unjust for the defendant to retain the benefit received? It also examines subsidiary issues such as the appropriate

B.P. Exploration Co. (Libya) Lid. v. Hunt (No. 2), [1982] 1 All E.R. 925 at 969 (Q.B.D.) [hereinafter B.P. Exploration]. Goff J.'s judgment was affirmed by the Court of Appeal (at 978) and by the House of Lords (at 986).

(1978), 83 D.L.R. (3d) 289 (S.C.C.) [hereinafter Rathwell].

lbid. at 306.

See generally P. Birks, An Introduction to the Law of Restitution, rev. ed. (Oxford: Clarendon Press, 1989); see also L.D. Smith, "The Province of the Law of Restitution" (1992) 71 Can. Bar Rev. 672.

Ibid. at 683-86.

See generally Goff and Jones, supra note 2 at 414-17; Birks, supra note 6 at 334-36; A. Burrows, The Law of Restitution (London: Butterworths, 1993) at 397-403; P.D. Maddaugh \& J.D. McCamus, The Law of Restitution (Aurora: Canada Law Book, 1990) at 432-38; G. Jones, "The Recovery of Benefits Gained from a Breach of Contract" (1983) 99 L.Q. Rev. 443; D. Friedmann, "Restitution of Profits Gained by Party in Breach of Contract" (1988) 104 L.Q. Rev. 383; L.D. Smith, "Disgorgement of the Profits of Breach of Contract: Property, Contract and 'Efficient Breach'" (1995) 24 Can. Bus. L.J. 121. 
method of valuing the defendant's enrichment and the relevance, if any, of the contract price to the valuation of the benefit.

\section{The Basic Position}

Despite the comparative paucity of authority, the law seems clear. A party who has performed services pursuant to a contract that it later, rightfully, treats as discharged because of the other's fundamental breach, is given an election. The party may either sue for damages for breach of contract in accordance with the normal rules or it may instead sue upon a quantum meruit for the reasonable value of the services rendered. An early example of this election is provided by De Bernardy v. Harding. ${ }^{9}$ The defendant was engaged in erecting seats to view the funeral procession of the Duke of Wellington for the purpose of letting them to the general public. He entered into an agreement with the plaintiff, a foreign agent, to advertise the scheme abroad and to dispose of tickets. The plaintiff was to be paid a percentage of the value of the tickets that he sold. After the plaintiff had incurred various expenses, but before he had sold any tickets, the defendant told the plaintiff not to dispose of any of the tickets since he, the defendant, would sell them on the spot. Accordingly, the plaintiff sent applicants for tickets directly to the defendant. The defendant however, refused to pay the plaintiff anything for his work and the plaintiff sued upon a quantum meruit. Alderson B. said:

Where one party has absolutely refused to perform, or has rendered himself incapable of performing, his part of the contract, he puts it in the power of the other party either to sue for a breach of it, or to rescind the contract and sue on a quantum meruit for the work actually done. ${ }^{10}$

In Lodder v. Slowey," the Privy Council agreed with the New Zealand Court of Appeal $^{12}$ as to the right of a contractor, having validly treated a contract as at an end because of the defendant's breach, to "sue for work and labour done instead of suing for damages for breach of the contract."'3

Canadian authority for this election is equally sparse but equally consistent. In Clermont v. Mid-West Steel Products Ltd. ${ }^{14}$ for example, Tucker J. said:

...I consider the principle applicable that where a party to a contract performs part of the work that he has undertaken and is then prevented by the fault of the other from proceeding further, the law does not allow him to be deprived of the fruits of his labour, i.e., reasonable remuneration on a quantum meruit basis for what he has done.... ${ }^{15}$

(1853), 8 Ex. 822, 155 E.R. 1586.

Ibid. at 1587 (E.R.).

[1904] A.C. 442 (P.C.).

(1901), 20 N.Z.L.R. 321 (C.A.).

Supra note 11 at 453.

(1965), 51 D.L.R. (2d) 340 (Sask. Q.B.). See also Festing v. Hunt (1890), 6 Man. R. 381 (Q.B.); Alkok v. Grymek (1968), 67 D.L.R. (2d) 718 (S.C.C.); Gettle Bros. Construction Co. Lid. v. Alwinsal Potash of Canada Lid. (1969), 5 D.L.R. (3d) 719 (Sask. C.A.), aff d (1970), 15 D.L.R. (3d) $128 \mathrm{n}$ (S.C.C.).

Ibid. at 356. 
The scope of the plaintiff's election was discussed at some length in Komorowski v. Van Weel. ${ }^{16}$ Sutherland $\mathrm{J}$. defined the election in the following terms:

[T] he plaintiffs could have elected to accept the defendants' repudiation and so treated their own performance obligations under the contract as terminated and in the latter event could have recovered either (i) damages for breach of contract or (ii) in quantum meruit (restitution) for the value of the work performed by them before the repudiation by the defendants. ${ }^{17}$

\section{The UnJust Factor}

Why should a plaintiff, on electing to treat the contract as discharged, have this further election of suing for damages or claiming on a quantum meruit for the value of services rendered? What makes it unjust for the defendant simply to retain the benefit received and pay damages for its breach of contract? It is in fact not readily apparent why the plaintiff in such a case should have a cause of action in unjust enrichment. ${ }^{18}$ Many of the early cases proceeded on the assumption that, in light of the defendant's repudiation, the plaintiff was entitled to "rescind" the contract and thus wipe it out altogether. This was, for example, how Alderson J. described the plaintiff's election in De Bernardy v. Harding. ${ }^{19}$ Equally, in Lodder v. Slowey, the Privy Council ${ }^{20}$ affirmed a judgment of the New Zealand Court of Appeal ${ }^{21}$ that was rife with references to rescission. ${ }^{22}$ In the leading American authority of Boomer v. Muir, ${ }^{23}$ Dooling J. said that a contractor, who was prevented from performing the contract by the other party's breach in failing to supply the necessary materials as required under the contract, had a choice of three remedies:

He may treat the contract as rescinded and recover upon a quantum meruit so far as he has performed; he may keep the contract alive, offering complete performance, and sue for damages for delay and expense incurred; or he may treat the repudiation as putting an end to the contract for purposes of performance and sue for the profits he would have realized. ${ }^{24}$

The fact that, under the first remedy, the contract was rescinded led the Court to conclude that a plaintiff's claim for the reasonable value of its services should not be restricted by the contract price. ${ }^{25}$ Dooling J. said:

(1993), 12 O.R. (3d) 444 (Gen. Div.). See also Campbell, Albo, Low Lid. v. Black (1995), 26 O.R. (3d) 111 (Gen. Div.).

$17 \quad$ lbid. at 459.

I* See Mr. Justice D. Byrme, "Benefits - For Services Rendered" in M. Mclnnes, ed., Restitution: Developments in Unjust Enrichment (Sydney: LBC Information Services, 1996) 87 at 99.

Supra note 9 at 1587 (E.R.).

Supra note 11.

Supra note 12.

See especially ibid. at 358-59, Williams $\mathrm{J}$.

24 P. 2d 570 (Cal. App. 1933) [hereinafter Boomer].

Ibid. at 573.

The question of whether a plaintiff's claim for restitution should be restricted by the contract price is dealt with in section $\mathrm{V}$, below. 
A rescinded contract ceases to exist for all purposes. How then can it be looked to for one purpose, the purpose of fixing the amount of recovery? ${ }^{26}$

It is now clear, however, that when an innocent party terminates a contract because of the defendant's fundamental breach, it is not rescinding the contract in the strict sense. It is simply electing to relieve itself of any obligations to perform in the future and, at the same time, to put an end to the primary obligations of the contract breaker to perform. The contract breaker, however, is not released from its obligation to pay damages for breach of contract. Thus, in Heyman v. Darwins Ltd., ${ }^{27}$ Lord Porter said in relation to a repudiatory breach of contract:

Strictly speaking, to say that on acceptance of the renunciation of a contract the contract is rescinded is incorrect. In such a case the injured party may accept the renunciation as a breach going to the root of the whole of the consideration. By that acceptance he is discharged from further performance and may bring an action for damages, but the contract itself is not rescinded. ${ }^{2 \mathrm{R}}$

The important point is that the contract is still alive for the purpose of giving the plaintiff the right to sue for damages and, indeed, for the purpose of potentially allowing the defendant to seek the protection of some exclusion clause. ${ }^{29}$ Most recently, in Komorowski v. Van Weel, ${ }^{30}$ Sutherland J. stressed the fact that the election of the innocent party to treat the contract as discharged on account of the defendant's breach did not entail the obliteration of the contract.

It can therefore be argued that there is no room for restitutionary relief since the contract still governs the parties' relationship, and the plaintiff still has a perfectly adequate remedy for breach of contract. There is, in Dickson J.'s words from Rathwell, ${ }^{31}$ a "juristic reason" for the defendant's enrichment - the contract pursuant to which the services were provided. While it is equally true that frustration does not work a rescission of the contract, and yet restitutionary relief is available, the plaintiff in such a case does not possess the right to bring an action for breach of contract. Given the consistency of the authority, however, it is difficult to deny the availability of restitutionary relief in these circumstances. ${ }^{32}$

Boomer, supra note 23 at 577.

[1942] A.C. 356 (H.L.).

lbid. at 399. See also Johnson v. Agnew, [1980] A.C. 367 (H.L.).

See Photo Production Lid. v. Securicor Transport Ltd., [1980] A.C. 827 (H.L.).

Supra note 16.

Supra note 4 at 306.

It is worth noting that, at one time, Goff \& Jones also took the view that the plaintiff should be confined to its remedy in damages for breach of contract: Mr. Justice R. Goff \& G. Jones, The Law of Restitution, 2d ed. (London: Sweet and Maxwell, 1978) at 380. It has been pointed out that there was an inconsistency in the approach taken by Goff and Jones because they always supported the innocent party's right to recover money paid for a total failure of consideration pursuant to a contract discharged for breach: M. Gamer, "The Role of Subjective Benefit in the Law of Unjust Enrichment" (1990) 10 Oxf. J. Leg. Stud. 42 at 55 n.69. Garner must be correct that claims for money paid and for services rendered should be treated alike. Garner in fact rejects, on principle, the restriction of the plaintiff to its contractual remedies since it "contracted to obtain the defendant's promised performance" and "did not purchase a right to damages": ibid. at 55 . 
There has been little discussion in the cases of the basis for such restitutionary relief. What precisely is the factor that renders the defendant's enrichment unjust? Goff and Jones $^{33}$ intimate that the primary basis for restitutionary relief in these cases is that the defendant has freely accepted the services with the knowledge that the plaintiff expected to be paid for them. This view has the support of some of the authorities. In lezzi Constructions Pty. Ltd. v. Watkins Pacific (Qld.) Pty. Ltd. ${ }^{34}$ for example, the Queensland Court of Appeal indicated that the plaintiff's restitutionary claim was grounded in the defendant's acceptance of the benefit received. In this regard, the Court relied heavily upon the reasoning of Deane J. in Pavey \& Matthews Pty. Ltd. v. Paul $^{35}$ a case dealing with a claim on a quantum meruit for services rendered under an unenforceable contract, in which Deane J. had spoken of the law's recognizing "an obligation to pay a reasonable remuneration or compensation for a benefit actually or constructively accepted." ${ }^{36}$

One problem with the theory of free acceptance in this context is the argument that, where the contract is entire, the defendant has expressed a willingness to accept and pay only for the completed work, and not for the work as it progresses from time to time. ${ }^{37}$ It is perhaps for this reason that Deane J. in Pavey referred to a benefit being "actually or constructively accepted." 38 Moreover, free acceptance should be determined at the time when the services are being performed. Yet, at that time, the defendant intended to pay for the work and so it is difficult to say that the defendant failed to avail itself of "a reasonable opportunity open to [it] to reject the proffered services." ${ }^{\prime 39}$ The later breach of contract by the defendant simply comes too late. Birks has stated:

Free acceptance, if it works at all, works because of the unconscientiousness of the recipient in not availing himself of the opportunity to save the intervener from the risk. The unconscientious nature of the resulting receipt is what justifies tipping the balance in favour of the intervener and allowing the quantum meruit. Garner ${ }^{40} \ldots$ draws a distinction between "initial unconscionability" and "supervening unconscionability." In the latter there is nothing unconscientious in the recipient's behaviour at the time of receipt but, later, he changes his mind and decides not to pay. It is obvious that "supervening unconscionability" has little or no weight in tipping the balance between a risktaking intervener and the initially innocent recipient."

Supra note 2 at 404.

[1995] 2 Qd. R. 350 (C.A.).

(1987), 162 C.L.R. 221 (Aus. H.C.) [hereinafter Pavey].

lbid. at 257.

See Birks, supra note 6 at 286-87.

Pavey, supra note 35 at 257 [emphasis added].

This quotation is drawn from the definition of the principle of free acceptance set out in Goff \& Jones, supra note 2 at 19.

Supra note 32 at 48.

$4 \quad$ P. Birks, "In Defence of Free Acceptance" in A. Burrows, ed., Essays on the Law of Restitution

(Oxford: Clarendon Press, 1991) 105 at 111. 
Some writers ${ }^{42}$ have even gone so far as to suggest that the principle of free acceptance is not, and should not be, the basis for a restitutionary claim.

The most convincing ground for the restitutionary claim in respect of services rendered under a contract discharged for the defendant's breach is that proposed by Burrows: failure of consideration. ${ }^{43}$ In other words, the plaintiff performed services on the basis that it would enjoy some reciprocal performance from the defendant. That basis has been destroyed by the defendant's repudiatory breach.

The recognition of failure of consideration as the factor rendering the defendant's enrichment unjust in the case of services also has the merit of achieving symmetry with claims for money paid. Such claims have traditionally depended upon the plaintiff establishing a failure of consideration. ${ }^{44} \mathrm{~A}$ major stumbling block to restitutionary relief for money paid, however, has been the traditional insistence that the failure of consideration be total. ${ }^{45}$ This requirement has caused problems in situations where, for example, the plaintiff has enjoyed the use of property delivered under a contract that was later terminated for the defendant's breach. It has been severely, and justly, criticized by the writers as an unnecessary and illogical restriction on restitutionary relief. $^{46}$ It is worth noting that of late the courts have shown themselves willing to challenge the requirement to some degree. In Goss v. Chilcott, ${ }^{47}$ Lord Goff, speaking for the Privy Council and relying on statements from the Australian High Court, ${ }^{48}$ said:

[A]t least in those cases in which apportionment can be carried out without difficulty, the law will allow partial recovery [of money paid] on [the] ground [of failure of consideration]...."9

Moreover, Maddaugh and McCamus ${ }^{\mathrm{s0}}$ have pointed to a number of Canadian decisions where buyers of goods, upon terminating the contract for the seller's fundamental breach, have been allowed to recover money paid despite often substantial use of the property in the interim. Gibbons v. Trapp Motors $L t d^{\text {sI }}$ provides a useful illustration of this jurisdiction. The plaintiff purchased a new car that immediately displayed various defects. The Court held that he was entitled to return the car and recover his purchase price less a reasonable allowance for the ten months during which he had used the car. In Gibbons, as in the other cases, the Court did not characterize the plaintiff's claim as one in restitution for money paid upon a failure of consideration, but described

\footnotetext{
42 See especially A. Burrows, "Free Acceptance and the Law of Restitution" (1988) 104 L.Q. Rev. 577.

43. See generally chapter 9 of Burrows, supra note 8. See also Birks, supra note 41 at 109-15.

44 See generally Goff \& Jones, supra note 2 at 417-24.

4s Ibid.

46. See, for example, Burrows, supra note 8 at 259-61.

$47 \quad$ [1996] 3 W.L.R. 180 (P.C.).

4k David Securities Pty. Lid. v. Commonwealth Bank of Australia (1992), 175 C.L.R. 353 at 383 (Aus. H.C.). Supra note 47 at 188 . Supra note 8 at 424 .

(1970), 9 D.L.R. (3d) 742 (B.C.S.C.) [hereinafter Gibbons].
} 
it as one for damages to compensate the plaintiff for his loss. In essence, however, it was a claim in restitution.

In the context of services rendered, where the courts have not traditionally used the language of failure of consideration, there has been no difficulty in awarding the plaintiff reasonable remuneration while deducting from that sum the value of any benefits received by the plaintiff pursuant to the contract. Thus, in Gettle Bros. Construction Co. Ltd. v. Alwinsal Potash of Canada Ltd. ${ }^{52}$ some $\$ 56,000$ had been paid to a contractor on account and this amount was deducted from the reasonable value of the plaintiff's services, $\$ 96,000$, to leave a balance of $\$ 40,000$. It should be noted, that in Gettle, as in the other cases where relief has been granted despite the conferral of benefits on the plaintiff by the defendant, the defendant had paid money to the plaintiff and counter-restitution was, therefore, a simple matter.

An interesting question is whether restitutionary relief should be available when the innocent party has rendered full performance of services due under the contract, and thus is entitled to sue for the contract price. In Morrison-Knudsen Co. Inc. v. British Columbia Hydro and Power Authority, ${ }^{53}$ the British Columbia Court of Appeal decided that, in such circumstances, the innocent party was restricted to claiming amounts due under the contract plus damages for any loss caused by the defendant's breach. In that case, the plaintiff had been hired by the defendant to construct a dam. In the course of performance, the defendant committed various breaches of the contract that were sufficiently fundamental as to have justified the plaintiff in terminating the contract; however, the plaintiff did not discover that these breaches were fundamental until after completing the work. The Court held that the plaintiff was limited to relief under the contract and could not proceed by way of a claim on a quantum meruit in restitution for the reasonable value of the services provided. The Court pointed out that, in all of the previous English and Canadian cases $^{54}$ allowing a restitutionary quantum meruit, the plaintiff had accepted the defendant's repudiatory breach before it had completed performance of the work. It also drew support from American authority. ${ }^{55}$

In reaching its conclusion, the Court indicated that no relief in restitution was available whilst the contract remained "open and alive." ${ }^{\text {I }}$ In such an eventuality, the contract was the sole "source of any remedy open to the injured party." 57 Once the plaintiff had completed performance under the contract, it was too late to accept the defendant's repudiation since the plaintiff no longer required relief from future performance and had an adequate remedy in contract:

Supra note 14.

(1978), 85 D.L.R. (3d) 186 (B.C.C.A.) [hereinafter Morrison-Knudsen].

Among other cases, the Court relied upon Planche v. Colburn (1831), 8 Bing. 14, 131 E.R. 305

(C.P.); De Bernardy v. Harding, supra note 9; Lodder v. Slowey, supra note 11; and Van Wezel v. Risdon (1952), 7 W.W.R. 646 (Alta. S.C.).

This is indeed the general position in the United States, see G.E. Palmer, The Law of Restitution (Boston: Little Brown, 1978) vol. $1, \S 4.3$.

Morrison-Knudsen, supra note 53 at 229.

Ibid. 
The [plaintiffs] can recover the value they fixed for the work when they entered into the contract. If in addition there have been breaches, damages can be awarded. There is no performance due under the contract from which the [plaintiffs] ought to be released. After performance in a case such as this, if a fundamental breach is discovered, the innocent party has an adequate remedy and there is no need for the Courts to impose an award of quantum meruit. ${ }^{5 x}$

The Court said that, in effect, there was no injustice in restricting the plaintiff to its remedies under the contract since the method for compensating it for the work done was already at hand - the contract price. ${ }^{59}$ In the same vein, the Court added:

If the [plaintiffs] are given the full contract price, including the price for extra work, and full compensation for any damage flowing from breaches, we do not consider that the result would be unfair or inequitable or unjust. It may be that they will lose money on the job, but there is nothing inherently unjust, inequitable or unfair about that. Their bid may have been low or they might not have worked efficiently.

If it could be shown that no remedy other than quantum meruit would do justice between the parties, it may be that quantum meruit would follow. That seems to have been its history. But it has not been shown that the contract price plus compensation for breaches will result in unjust enrichment or any other type of injustice that has led to an award of quantum meruit in the past. By this we do not suggest that the boundaries of restitution are fixed, they are not, but they will move only to fill a need. That need has not been shown under the circumstances here. ${ }^{(x)}$

Goff and Jones support the position taken by the British Columbia Court of Appeal as being "historically sound" and "correct in principle." "1 The quantum meruit claim was allowed because the plaintiff could not sue in debt in respect of part performance; however, having completed its side of the contract, the plaintiff could sue in debt. Equally, Maddaugh and McCamus are in favour of the approach in Morrison-Knudsen on the basis that the claim under the contract would give the plaintiff "precisely what he expected to receive under the agreement." ${ }^{62}$ The view of Palmer in the United States is to the same effect:

Enforcement of the money promise gives the plaintiff the consideration he bargained for in return for his performance. The general policy of holding parties to their contracts supports the refusal of restitution. ${ }^{63}$

Goff and Jones ${ }^{64}$ would apply the same rule when the plaintiff has substantially performed its part of the contract on the ground that, in that situation also, the plaintiff has its action for the contract price. ${ }^{65}$ There is American authority to support this

\author{
$58 \quad$ Ibid. at 232. \\ $59 \quad$ Ibid. at 234. \\ w Ibid. at 248. \\ 6) Supra note 2 at 424. \\ $62 \quad$ Supra note 8 at $\mathbf{4 2 8 .}$ \\ 6. Supra note 55 at 379 \\ is Supra note 2 at 424. \\ w5 Such a case was Hoenig v. Isaacs, [1952] 2 All E.R. 176 (C.A.).
}


view. ${ }^{66}$ Maddaugh and McCamus are a little more circumspect. They make the good point that the concept of substantial performance has sometimes been interpreted generously since it allows relief to a party in breach for work done under an entire contract. ${ }^{67}$ Traditionally, such a party would be unable to claim on a quantum meruit for the value of services rendered. ${ }^{68}$ It is certainly true that the courts have given inconsistent interpretations to the concept of substantial performance. ${ }^{69}$

In contrast to the other writers, Burrows sees no reason to deny restitutionary relief to the plaintiff who has fully or substantially performed its part of the bargain:

[A]ssuming the plaintiff can, and has elected to, terminate the contract it seems illogical to deny restitution in the more extreme case of substantial performance, while allowing it for partial performance. $^{7 \prime}$

Burrows also points out ${ }^{71}$ that there is no barrier to restitutionary relief to a party who has paid the full purchase price for goods and has received, or is taken to have received, ${ }^{72}$ nothing in return.

Burrows is right to point out the anomaly which is especially stark if, as appears to be the case, ${ }^{73}$ the plaintiff, when suing on a quantum meruit, is not restricted to the contract price. Indeed, there have been cases where a plaintiff, suing upon a quantum meruit for part performance, has recovered substantially more than the contract price. The most notorious example is Boomer v. Muir ${ }^{74}$ from California where the plaintiff was awarded a sum almost thirteen times as high as the amount remaining due under the contract.

More fundamentally, the reasoning in Morrison-Knudsen throws into doubt the basis for restitutionary relief where the plaintiff has partly completed the contract. The Court said that there was nothing unjust in restricting the plaintiff to its relief under the contract. Whilst it was true that the plaintiff might lose money, that would be because it had made a bad bargain or had carried it out inefficiently. Moreover, there was no need to turn to restitutionary relief to prevent an unjust enrichment because the plaintiff had an adequate remedy in contract. Precisely the same argument could be made in a case of part performance and, as has been suggested here, should be so made.

See Palmer, supra note 55 at $379-80$.

Maddaugh \& McCamus, supra note 8 at 428.

See generally Goff \& Jones, supra note 2 at 438-47; Maddaugh \& McCamus, ibid. at 443-46; S.M. Waddams, "Restitution for the Part Performer" in B.J. Reiter \& J. Swan, eds., Studies in Contract Law (Toronto: Butterworths, 1980) 151.

See Waddams, ibid. at 154-57.

Supra note 8 at $270-71$.

Ibid. at 271 .

As in the famous case of Rowland v. Divall, [1923] 2 K.B. 500 (C.A.).

See the discussion in section $\mathrm{V}$, below.

Supra note 23. 


\section{THE ENRICHMENT}

A special problem is raised where the plaintiff has performed services that, at the time of the contract's termination, have not resulted in any apparent benefit to the defendant. This was the situation in Planche v. Colburn. ${ }^{75}$ The defendants had started a periodical publication entitled The Juvenile Library. They had hired the plaintiff for $£ 100$ to write a volume for the series on "Costume and Ancient Armour." After the plaintiff had written part of the volume, and was still ready and willing to complete and deliver the manuscript for inclusion in the periodical, the defendants abandoned the project and refused to pay the plaintiff. The plaintiff declined to tender to the defendants so much of the work as had been completed. Despite this failure to deliver, the Court allowed the plaintiff to succeed upon a quantum meruit. Bosanquet J. said:

[I]t is said that the Plaintiff ought to have tendered or delivered the work. It was part of the contract, however, that the work would be published in a particular shape; and if it had been delivered after the abandonment of the original design, it might have been published in a way not consistent with the Plaintiff's reputation, or not at all. ${ }^{\text {" }}$

The writers are divided as to whether Planche is truly a decision in the law of restitution or whether, given the lack of any objective enrichment, it belongs more properly to the category of contract law and the measure of damages for breach.

In support of Planché as a restitution case, Maddaugh and McCamus argue that "in providing the services requested by the defendant, the plaintiff was conferring a benefit upon him."77 Birks takes a similar view, though he points out that it is essential to distinguish between acts that constitute part of the requested contractual performance and those that are preliminary, or ancillary, to the requested contractual performance. ${ }^{78}$ This indeed appears to be the position in the United States, where the same distinction is drawn between "expenditures in preparation for performance and those in actual performance of a contract."79

A good illustration of the sort of questions that have to be addressed is provided by Acme Process Equipment Co. v. United States. ${ }^{80}$ The plaintiff entered into a contract to provide rifles to the Government of the United States, but after the contract had been partly performed and some of the rifles had been delivered, the defendant wrongfully cancelled the contract. Rather than claiming damages for breach of contract, the plaintiff wished to sue in restitution for the reasonable value of services performed pursuant to the contract. The defendant argued that the plaintiff's recovery in restitution should be restricted to the reasonable value of the rifles delivered prior to the 
termination of the contract since no benefit had been conferred on the defendant beyond those rifles. The Court, however, rejected that view:

Acme's recovery is not limited to the value of the goods received by the Government under the contract; rather, it can be based on the reasonable value of the entire performance."

In reaching this conclusion, the Court pointed out that the contract between the parties was not simply one to supply a finished article but "to 'furnish and deliver' specified items (emphasis added). The entire precontract negotiations were based on the assumption that it was Acme which would manufacture the requested rifles." 82 Therefore, it could not be said that the plaintiff's services were merely preparatory to contractual performance. The importance to the plaintiff of a restitutionary claim, as in so many of the American cases, lay in the fact that the plaintiff had clearly made a losing contract and hence contractual damages would not serve its purpose. ${ }^{83}$

It is worth noting that, in Acme, the Court had some difficulty in dealing with the wording of the Restatement of Contracts. ${ }^{84}$ The same difficulty exists with the Restatement of Contracts $2 d^{85}$ Section 370 provides:

A party is entitled to restitution ... only to the extent that he has conferred a benefit on the other party by way of part performance or reliance.

The comment to this section states:

[A] party's expenditures in preparation for performance that do not confer a benefit on the other party do not give rise to a restitution interest.... If, for example, the performance consists of the manufacture and delivery of goods and the buyer wrongfully prevents its completion, the seller is not entitled to restitution because no benefit has been conferred on the buyer. ${ }^{86}$

In contrast to the position adopted by Maddaugh and McCamus and Birks, Burrows $^{87}$ takes the view that Planche v. Colburn ${ }^{88}$ is not truly a restitutionary case. He believes it to be essential to a restitutionary claim that the defendant have been benefited in some objective manner. In the case of services, that means that they must have been received: "Services designed to produce an end product are received when part of the end product is transferred" whereas "[p]ure services are received when

nI Ibid. at 530.

k2 lbid. at 529-30.

*. See the discussion in section $\mathrm{V}$, below.

*4 $\$ 348$ (St. Paul: American Law Institute Publishers, 1932).

xs (St. Paul: American Law Institute Publishers, 1981).

*. To make the point, the Restatement, ibid,, offers the following illustration (number 2):

A contracts to sell $B$ a machine for $\$ 100,000$. After $A$ has spent $\$ 40,000$ on the manufacture of the machine, but before its completion, B repudiates the contract. A cannot get restitution of the $\$ 40,000$ because no benefit was conferred on $B$.

x7 Supra note 8 at 8-9.

*x Supra note 54 . 
performance starts." ${ }^{89}$ To Burrows, therefore, Planché is better regarded as a case on contractual damages. ${ }^{90}$ Beatson and Garner are similarly critical of the restitutionary nature of Planché, though for different reasons. Beatson"1 argues that pure services cannot constitute an enrichment in the recipient's hands and to treat them as such is to marginalize reliance based liability at the expense of "an overinclusive concept of 'unjust enrichment.'"'92

Garner agrees with Beatson that "objective benefit requires utility, and that this necessitates that the services pass the exchange value test either by positively adding to the defendant's stock of wealth, or by saving him an expense that he otherwise would have had to incur." 93 Thus, the provision of services, especially "pure services," will not often give rise to an objective benefit. Garner, ${ }^{94}$ however, recognizes the concept of "subjective benefit" where the defendant has indicated that he or she values the work done by the plaintiff, even though it may have no objective value. The clearest case of such an indication would be where the defendant has requested the services in question on the understanding that they would be paid for and where the plaintiff has fully complied with that request. In general though, part performance by a plaintiff would be insufficient to ground a subjective benefit because the defendant did not bargain for part performance. ${ }^{95}$ The plaintiff would have to show that, following the breach, the defendant acknowledged the benefit of the plaintiff's services by, for example, completing the work started by the plaintiff. ${ }^{96}$ Thus, according to Garner, ${ }^{97}$ Planché v. Colburn ${ }^{98}$ was not a restitutionary case as there was no acknowledgment by the defendant of any benefit. Rather, it should be viewed as a case where "contractual damages were awarded on a reliance loss basis." ${ }^{99}$

Goff and Jones are more equivocal in their treatment of Planché. On the one hand, they write that "a defendant should be deemed to have received a benefit only if he has received an objective benefit, in the sense that he cannot deny that he has made a realizable gain or has been saved an expense."100 This statement would suggest that the claim in Planche should not be regarded as restitutionary because no part of the manuscript had been tendered to the defendant. Indeed, Goff and Jones also note that it is "doubtful whether Planché v. Colburn was a claim in quasi-contract." ${ }^{101}$ On the

Supra note 8 at 9.

lbid. at 267 n. 2 .

See generally J. Beatson, "Benefit, Reliance and the Structure of Unjust Enrichment" in The Use and Abuse of Unjust Enrichment: Essays on the law of Restitution (Oxford: Clarendon Press, 1991) c. 2.

lbid. at 44.

M. Garner, "Benefits - For Services Rendered: A Commentary" in McInnes, ed., supra note 18, 109 at 112.

See generally Garner, supra note 32 .

lbid. at 53.

Ibid. at 54. This is Gamer's justification of Lodder v. Slowey, supra note 11.

Ibid. at 53-54.

Supra note 54.

Garner, supra note 32 at 53 .

Goff \& Jones, supra note 2 at 21.

lbid. at $426 \mathrm{n} .35$. 
other hand, they write that when the party in breach has prevented performance he cannot be heard to say that "the plaintiff's performance [did] not correspond to [the] requested performance." 102 Goff and Jones' conclusion is also somewhat ambiguous:

[A] restitutionary claim should lie only if the defendant had, or could have, received an objective benefit which he bargained for. ${ }^{103}$

What exactly is meant by the italicized words?

The view that the party in breach cannot deny the receipt of a benefit is supported by Byrne $\mathbf{J}$. in Australia, writing extrajudicially:

It is another question where the services provided prior to determination are of such a character or amount that they do not advance the contractual objective, for example preliminary sketches for a portrait. But even in such a case, it is not difficult to suppose that whatever was done pursuant to the determined contract was done in furtherance of the interests of the repudiating party, so that it should not lie in the mouth of that party to deny the existence of benefit with the consequence that the innocent service-provider is denied payment. ${ }^{104}$

In Brenner v. First Artists' Management Pty. Ltd., ${ }^{105}$ Byrne J., in a different context, similarily stated that the existence of a benefit must be viewed from the position of the defendant, and seemingly approved of Planche v. Colburn ${ }^{106}$ and its place in the law of restitution. He said:

[W] here a person requests another to do something, it is not unreasonable for the law to conclude that the former sees some benefit in its performance, however wrong this view may be on an objective basis and for the law to act upon the perception of the recipient. ${ }^{\text {!n? }}$

There is much to be said for Burrows' view that no benefit was conferred on the defendant in a case like Planche v. Colburn and that to extend restitutionary relief to that situation is to distort the concept of unjust enrichment. In essence, the plaintiff was claiming the reliance loss that flowed from the defendant's breach of contract. Of course, if the view is accepted that the innocent party should not be entitled to elect to claim in restitution when faced with the defendant's repudiatory breach, the Planche scenario would no longer pose a problem.

Once the objective benefit has been conferred in the Burrows' sense, then it follows that the defendant should not be free to deny the benefit by arguing that it was willing to pay only for complete, and not part, performance. This is where the statement in Goff and Jones becomes relevant - the defendant has prevented complete performance

\footnotetext{
1112 lbid. at 424 n.23.

III3 Ibid. at 426 [emphasis added].

Iit Supra note 18 at 100.

IIIS [1993] 2 V.R. 221 (S.C.) [hereinafter Brenner].

Hix. Supra note 54.

$1117 \quad$ Brenner, supra note 105 at 258.
} 
by the breach and thus "is precluded from saying that the plaintiff's performance does not correspond to [the] requested performance." 108 Burrows would reach the same conclusion by his "bargained for" principle of benefit. ${ }^{109}$ Under this test, the defendant has indicated by its promise to pay that it regards the services as beneficial in that it has been saved an expense that it would have been willing to incur. Burrows then deals with the issue of part performance:

By similar reasoning, even if the defendant receives only part of what he bargained for, it can be rebuttably presumed that he regards himself as benefited by what he has received and that he has been saved part of the expense that he would otherwise have incurred."

Birks uses the concept of "limited acceptance" to reach the same result."

\section{Valuation of the Enrichment - A Contractual Ceiling?}

The final issue to be addressed is the valuation of the benefit received by the defendant. The general rule is that services should be paid for at the general market rate. $^{112}$ One question that arises is whether this test should apply even when the services have resulted in some end product. Should the benefit be assessed by reference to the value of what has been produced in the defendant's hands? In B.P. Exploration Co. (Libya) Ltd. v. Hunt (No. 2), ${ }^{113}$ the Court was dealing with relief pursuant to the English Law Reform (Frustrated Contracts) Act $1943^{114}$ for services rendered prior to the frustrating event. In construing the relevant provision, ${ }^{115}$ Goff J. concluded that, in a case where services were designed to result in an end product, "benefit" referred to that end product rather than the services themselves. He indicated however, that were the matter not resolved by the wording of the statute, he would have preferred "to treat the services themselves as the benefit." 116 Since the services had been requested by the defendant, that party should take the risk that they might "prove worthless, from whatever cause."117 Certainly the cases that have awarded restitutionary relief for services rendered pursuant to a contract discharged for the defendant's breach seem to have assumed that the services themselves constitute the benefit rather than any end product. ${ }^{18}$

Supra note 2 at 424 n.23.

See generally Burrows, supra note 8 at 14-15.

Ibid. at 14.

Supra note 6 at 126-27.

Goff \& Jones, supra note 2 at 28-29.

Supra note 3.

$6 \& 7$ Geo. 6, c. 40.

Section 1(3).

B.P. Exploration, supra note 3 at 940.

Ibid.

11x Garner takes the position that, when the plaintiff can establish a "subjective benefit," it should be measured by the value of the services themselves. Where, however, the enrichment can only be identified objectively, then "it should be valued accordingly, that is, by reference to the exchange value of the end product, and not the market value of the services provided." See Garner, supra note 93 at 113 . See also generally Garner, supra note 32 . 
A theoretically difficult question is whether the value of the benefit conferred, and hence the amount recoverable by the plaintiff, should be restricted in some way by the price payable by the defendant for complete performance. If there is no such limitation, then clearly the restitutionary alternative, when available, will be highly attractive to a plaintiff who has made a bad bargain. It is clear law that a party suing for damages for breach of contract cannot avoid the consequences of a bad bargain by claiming its reliance loss rather than its expectation loss. In other words, the plaintiff can be met with the defence that the contract was a losing proposition and that it would have lost money even if there had been no breach of contract and the agreement had been fully performed. The leading Canadian authority is Bowlay Logging Ltd. v. Domtar Ltd. ${ }^{119}$ where Berger J. said at trial:

The law of contract compensates a plaintiff for damages resulting from the defendant's breach; it does not compensate a plaintiff for damages resulting from his making a bad bargain. Where it can be seen that the plaintiff would have incurred a loss on the contract as a whole, the expenses he has incurred are losses flowing from entering into the contract, not losses flowing from the defendant's breach. In these circumstances, the true consequence of the defendant's breach is that the plaintiff is released from his obligation to complete the contract - or in other words, he is saved from incurring further losses. ${ }^{120}$

However, Berger J., also made it clear that the burden of establishing that the plaintiff would have lost money falls squarely on the defendant. ${ }^{121}$

There are some indications in the case law that a plaintiff may be able to avoid the consequences of a bad bargain by claiming its reliance loss in the tort of negligent misstatement where that option is available. ${ }^{122}$ The present question is whether a similar result can be achieved through the vehicle of restitution.

The authorities on this issue are sparse, but consistent. Whilst the contractual price is good evidence of the reasonable value of the plaintiff's services, ${ }^{123}$ it is not conclusive and does not constitute a cap on the amount recoverable on a quantum meruit. In Lodder v. Slowey, the Privy Council ${ }^{124}$ accepted the reasoning of the New Zealand Court of Appeal ${ }^{125}$ as to the appropriate basis on which to assess the plaintiff's quantum meruit claim. In the Court of Appeal, Williams J. pointed out that, in any claim for damages for breach of contract, the Court would have to take into account the profits, or losses, that the plaintiff would have gained, or sustained, had the contract been completed. The situation, however, was different with a claim upon a

[1978] 4 W.W.R. 105 (B.C.S.C.), aff d(1982), 135 D.L.R. (3d) 179 (B.C.C.A.). See also $C . \& P$. Haulage v. Middleton, [1983] I W.L.R. 1461 (C.A.).

Ibid. at 117 (B.C.S.C.).

See also C.C.C. Films (London) Lid. v. Quadrant Films Ltd., [1985] 1 Q.B. 16.

See in particular Rainbow Industrial Caterers Lid. v. Canadian National Railway (1991), 84 D.L.R. (4th) 291 (S.C.C.).

Renard Constructions (M.E.) Pty. Lid. v. Minister for Public Works (1992), 26 N.S.W.L.R. 234 at 278 (C.A.), Meagher J.A [hereinafer Renard]. 
quantum meruit. The contract had been rescinded by the plaintiff's acceptance of the defendant's repudiation, and so it was no longer relevant whether the plaintiff had made a profitable or a bad bargain. Williams J. said:

As the defendant has abandoned the special contract, and as the plaintiff has accepted that abandonment, what would have happened if the special contract had continued in existence is entirely irrelevant. As by the consent of both parties the special contract has been set aside, neither can the plaintiff claim for any profit he might have made under it nor can the defendant set up that if the plaintiff had been allowed to complete his performance of the contract he would have made no profit or would have suffered a loss. ${ }^{126}$

It should be noted that, in reaching its conclusion, the New Zealand Court of Appeal relied upon the now discredited theory that the plaintiff is entitled to "rescind" the contract when confronted with the defendant's fundamental breach.

The American courts have generally also taken the view that the plaintiff's restitutionary claim is not limited by the contract price. ${ }^{127}$ As has been seen from cases like Boomer v. Muir, ${ }^{128}$ often the theory of rescission has been used to buttress this conclusion.

Although they have not discussed the point in depth, Canadian courts also support the position that the plaintiff's recovery should not be limited by the contract price. Thus, in Lindsay v. Sutton ${ }^{129}$ an Ontario court, following Lodder v. Slowey, ${ }^{130}$ determined that the plaintiff building contractor was entitled to "the fair value of the work, without reference to the contract price."131 This conclusion was reached despite evidence to the effect that the plaintiff might well have suffered a loss had the contract been completed according to its terms; however, there were again unfortunate references to the contract being rescinded, seemingly in the strict sense.

In Van Wezel v. Risdon, ${ }^{132}$ an Alberta court also recognized that a claim on a quantum meruit might entitle a plaintiff to avoid some of the consequences of a losing contract. $^{133}$ Moreover, the Court did not rely upon the rescission of the contract. In Stevens \& Fiske Construction Ltd. v. Johnson, ${ }^{134}$ the Court recognized the possibility of a contractor suing upon a quantum meruit where the owner had abandoned the contract. It then indicated that, in such circumstances, "the price for which the

Ibid. at 358.

See generally Palmer, supra note 55 at $389-409$.

Supra note 23.

[1947] O.W.N. 951 (H.C.), rev'd on other grounds [1948] O.W.N. 252 (C.A.) [hereinafter Lindsay]. Supra note 11.

Lindsay, supra note 129 at 954.

Supra note 54.

Ibid. at 659.

(1973), 9 N.S.R. (2d) 608 (S.C.). See also Bruce Baird Construction Ltd. v. Guigues (1988), 34

Constr. L.R. 192 (Ont. D.C.). 
contractor was willing to perform that ... work may be some evidence of what would be reasonable...." 135

On a number of occasions where there has been no question of the plaintiff having made a bad bargain, the courts have used the contractual rate to value the plaintiff's services. ${ }^{136}$ Most recently, in Komorowski v. Van Weel, ${ }^{137}$ the Court also intimated that the contract price might set a limit on the plaintiff's recovery when it said:

A further principle ... is that the innocent contractor, not having done all of the work, is not permitted to recover on the basis of the whole contract price. ${ }^{138}$

Undoubtedly, the fullest discussion of this question in the Commonwealth was provided by the New South Wales Court of Appeal in Renard Constructions (M.E.) Pty. Ltd. v. Minister of Public Works. ${ }^{139}$ The case also involved a building contract. The plaintiff contractor was hired to construct two reinforced concrete pumping stations for a total price of about $\$ 209,000$. The defendant was found to have repudiated the contract before completion and this conduct justified the plaintiff's termination of the contract. The Court held that the plaintiff was entitled to recover $\$ 285,000$ on a quantum meruit claim, despite the fact that this sum, plus the amount of payments made to the contractor while the contract subsisted, was substantially in excess of the full contract price.

Meagher J.A. gave the reasons for judgment on this issue. He rejected, both on authority and on principle, the defendant's contention that the contract price should establish the ceiling of any quantum meruit claim. With respect to authority, Meagher J.A. relied upon the decision of the New Zealand Court of Appeal in Lodder v. Slowey, ${ }^{140}$ as affirmed by the Privy Council. ${ }^{141} \mathrm{He}$ also cited American authority, such as Boomer v. Muir. ${ }^{142} \mathrm{He}$ recognized that the authority of cases like Boomer was undermined to some extent by the Court's view that a termination for breach led to a rescission of the contract. Nevertheless, he found the reasoning on the irrelevance of the contract price to be persuasive.

On the issue of principle, Meagher J.A. pointed out that the innocent party had a choice of alternate remedies. Each remedy was designed to serve a different purpose and there was no anomaly in the fact that one remedy might provide a significantly different outcome from the other. If the innocent party chose to rely on a quantum meruit for the reasonable value of the work done, then the profit, or loss, that it would

Ibid. at 619 quoting from I. Goldsmith, Canadian Building Contracts, Ist ed. (Toronto: Carswcll, 1968) at 106 [emphasis added].

See e.g. Alkok v. Grymek, supra note 14.

Supra note 16.

Ibid. at 463.

Supra note 123. See M. McInnes, "Contractual Services, Restitution and the Avoidance of Bad Bargains" (1995) 23 Aus. Bus. L. Rev. 218.

Supra note 12.

Supra note 11.

Supra note 23. 
have made, or incurred, if the contract had been performed was simply irrelevant. Indeed, "it would be extremely anomalous if the defaulting party when sued on a quantum meruit could invoke the contract which he has repudiated in order to impose a ceiling on amounts otherwise recoverable."143

The reasoning in Renard Constructions was applied by the Queensland Court of Appeal in Iezzi Constructions Pty. Ltd. v. Watkins Pacific (Qld.) Pty. Ltd. ${ }^{144}$ In that case, McPherson J.A. said:

Once the contract is gone, it is the law that must determine whether payment should be made for the work done, and not the terms of an agreement that the parties have by their words and conduct finally put aside and discarded. ${ }^{\text {14s }}$

Thomas J. simply made the point that the obligation on the part of the defendant to pay the reasonable value of the plaintiff's services did not arise from the contract, but from its termination, and thus the terms of the contract could not apply directly to the assessment of the plaintiff's claim.

There also seems to be general agreement among the commentators that the plaintiff's claim should not, as a matter of principle, be restricted automatically to the contract price or some proportionate part thereof. Beatson, for example, believes that the case for restricting the plaintiff to the contract price, or some rateable proportion thereof, is weak provided that the necessary enrichment on the part of the defendant can be established. ${ }^{146}$ As a general matter, he points out that the damages remedy might provide less than adequate compensation, especially when the plaintiff is faced with difficulty in proving its expectation loss. He then rejects categorically the theory that the plaintiff should be awarded a proportionate part of the contract price for the work done, as that solution would be inequitable. The plaintiff never agreed to do half the work, for example, for half the price and there is no necessary reason why half the work should be worth only half the price. Beatson is of the opinion that it might make some sense to impose the contract price as a ceiling, since that was the maximum exposure to which the defendant consented, and the recovery of the full contract price would satisfy all of the plaintiff's expectations. On the other hand, anticipating the reasoning in Renard, ${ }^{147}$ he saw little reason why a contract breaker should be allowed to recover, albeit indirectly, part of its lost expectations. ${ }^{148}$ Furthermore, to apply the contract price as a cap would be to favour the party who had completed only a small part of the work over one who had performed the bulk.

\footnotetext{
14.3 Renard, supra note 123 at 278.

14 Supra note 34.

$145 \quad$ Ibid. at 362

146. J. Beatson, "What Can Restitution Do For You?" in The Use and Abuse of Unjust Enrichment, supra note 91,1 at 12-15. See also Maddaugh \& McCamus, supra note 8 at 427-28.

$147 \quad$ Supra note 123.

148 See also Palmer, supra note 55 at 393.
} 
Burrows fails to see that the granting of restitution unrestricted by the contract price subverts the law of contract. ${ }^{149}$ The plaintiff has terminated the contract for the defendant's breach and the restitutionary claim is independent rather than parasitic. $\mathrm{He}$ also points out that a claim to recover money on the ground of a total failure of consideration in respect of a contract discharged for the defendant's breach has never been met with the defence that the plaintiff had made a bad bargain. The best example of the last point is the famous American case of Bush v. Canfield. ${ }^{150}$ The defendant contracted to sell 2000 barrels of flour to the plaintiff for $\$ 7$ a barrel. The plaintiff paid $\$ 5000$ in advance and agreed to pay the balance on delivery. The defendant failed to deliver the flour. The plaintiff was allowed to recover the full $\$ 5000$ despite the fact that the flour was worth only $\$ 5.50$ a barrel at the date set for delivery.

Over the years, Goff and Jones have vacillated as to the best answer to this question. In the first edition of their textbook, ${ }^{151}$ the issue was not addressed at all. In the second edition, ${ }^{152}$ as has already been observed, they doubted whether the innocent party should have the right to elect to sue on a quantum meruit on the ground that damages should be an adequate remedy. If such an election were available, then the plaintiff should be restricted in its claim to a rateable proportion of the contract price since the services were rendered on the basis of that price. ${ }^{153}$ In the third edition, ${ }^{154}$ the authors no longer state explicitly that the restitutionary claim should be unavailable, but they still favour restricting the plaintiff to a proportionate part of the contract price. Most recently, Goff and Jones ${ }^{155}$ adopt the pragmatic solution that the plaintiff should never recover more than the full contract price. They see this approach as going some way towards protecting the parties' contractual expectations. They regard this consideration as important given the fact that, at the time the services were rendered, the contract was in full force and effect, and has been terminated only for the future. They also point out that, with a complex contract, it is not always easy to determine just which party was in breach. They recognize the potential inconsistency between this approach to remuneration for services rendered and the traditional view with respect to the recovery of money paid. They justify the distinction in part on the basis that the party seeking to recover money paid is not attempting to ignore the contract price.

Many of the arguments of Goff and Jones as to why the plaintiff's claim should be restricted in some way by the contract price seem to lend support to their original view that the plaintiff should be limited to a claim for damages for breach of contract.

\footnotetext{
14) Supra note 8 at 269. See also Birks, supra note 41 at $135-36$.

151 2. Conn. 485 (Ct. App. 1818).

151 R. Goff \& G. Jones, The Law of Restitution (London: Sweet \& Maxwell, 1966)

152 R. Goff \& G. Jones, The Law of Restitution, 2d ed. (London: Sweet \& Maxwell, 1978) at 379-80.

153 In this regard, Goff \& Jones preferred the approach of the Washington courts in Noyes v. Pugin, 27 P. 548 (1891). This is also the preferred solution in S.M. Waddams, The Law of Contracts, 3d ed. (Toronto: Canada Law Book, 1993) at 496-97.

154 R. Goff \& G. Jones, The Law of Restitution, 3d ed. (London: Sweet \& Maxwell, 1986).

iss Supra note 2 at 427-28. For this conclusion, the authors rely on the approach taken by the Oregon courts in Wuchter v. Fitzgerald, 163 P. 819 (1917).
} 
In similar vein, Carter argues that the breach of contract should not undermine the parties' allocation of risk as expressed by the contractual terms, including the price. ${ }^{156}$ The breach occurred after the formation of the contract and does not operate to obliterate the contract. Moreover, he would argue that cases like Renard ${ }^{157}$ should not be regarded as restitutionary since there was no actual acceptance of the benefit. Rather, they should be regarded as claims for damages for breach of contract and, in any such claims, the contract price is relevant. ${ }^{158}$

Assuming that the innocent party is permitted to launch a restitutionary claim, then it makes sense for the reasons identified by Beatson that such relief should not be restricted per se by the contract price. This conclusion does not mean that the terms of the contract should be irrelevant for all purposes. It has already been seen that the terms of the contract will provide good evidence of the reasonable value of the plaintiff's services. Moreover, as Byrne J. has observed, ${ }^{159}$ care should be taken to ensure that a party who has made a bad bargain is not simply attempting to manipulate the defendant into repudiating the contract. Presumably, the parties are also free, by the terms of their contract, and subject to the normal rules of interpretation, to exclude an obligation to make restitution. ${ }^{160}$

More fundamentally, the point has been made that the contract price must be relevant to the determination of the benefit received by the defendant. ${ }^{161}$ Unless the plaintiff has conferred an "incontrovertible benefit" 62 on the defendant, such as money, then the defendant should be entitled to argue that it was not necessarily willing to pay the market value of the services, for example, provided by the plaintiff. The defendant should be allowed to "subjectively devalue" 163 the services by arguing that it was willing to pay for those services only at the contractual rate. Thus, according to this theory, in the absence of an incontrovertible benefit the defendant should be required to pay for the services provided at the contractual rate and the pro rata contract price should form the limit of the plaintiff's recovery. Equally, services performed under a contract with no expectation of payment would not generate any obligation on the part of the recipient to pay for them. ${ }^{164}$

The main argument against this approach is the one proposed in Renard, ${ }^{165}$ namely that a contract breaker, as a wrongdoer, cannot plead in aid a contract that it has repudiated. Maddaugh and McCamus have expressed this view in the proposition that

J. Carter, "Restitution and Contract Risk" in M. McInnes, ed., supra note 18, 137 at 156-57. Supra note 123.

Carter, supra note 156 at 157.

Supra note 18 at 105 n. 98.

See Carter, supra note 156 at $158-59$.

Burrows, supra note 8 at 268-71; Birks, supra note 41 at 135-37; McInnes, supra note 139.

See generally Goff \& Jones, supra note 2 at 22-26; Birks, supra note 6 at 116-24; Burrows, supra note 8 at 9-11; Maddaugh \& McCamus, supra note 8 at 42-44; M. McInnes, "Incontrovertible Benefits in the Supreme Court of Canada: Peel (Regional Municipality) v. Canada; Peel (Regional Municipality) v. Ontario" (1994) 23 Can. Bus. L. J. 122.

The concept of subjective devaluation was first developed by Birks, supra note 6 at 109-14.

Birks, supra note $4 \mathrm{I}$ at 136; and Komorosssi v. Van Weel, supra note 16.

Supra note 123. 
the contract breaker should be subjected to the presumption, seemingly irrebuttable, that it needed the work done and hence, were it not for the repudiated contract, would have been willing to pay the going market rate. ${ }^{166}$

The problem with the theory based on the principle of subjective devaluation is that the plaintiff would not necessarily have agreed to perform part of the contract for a proportionate part of the contract price. Moreover, if the courts were to adopt it, it would lend some support to the view expressed here that the plaintiff should be restricted to a claim for damages for breach of contract.

\section{Conclusion}

The issue of restitutionary relief to the innocent party for services rendered prior to the discharge of a contract for breach is apparently a simple one, yet it involves the resolution of some of the fundamental questions in the law of restitution. This article has tried to show that there is no need to give the plaintiff an alternative claim in restitution - the plaintiff should be content with the normal remedies for breach of contract. When the plaintiff entered into the contract, it was assuming the risk that the defendant might break the contract, whether in some fundamental way or not. The plaintiff has chosen to make the contract on the terms agreed, and there is nothing unfair in restricting its remedies to that bargain. Moreover, many of the proposed limitations on the plaintiff's restitutionary action, such as the rejection of Planche v. Colburn ${ }^{167}$ and the restriction of the plaintiff to the contract price, pro rata or otherwise, implicitly support the denial of a restitutionary claim. 